\title{
Reporting and Reparations: News Coverage and the Decision to Compensate the Forcefully Sterilized in North Carolina
}

\author{
J. P. Nelson ${ }^{1}$, Terri B. Davis ${ }^{1}$, Lacey Atkins ${ }^{2}$ \\ ${ }^{1}$ Department of Political Science, Lamar University, Beaumont, TX, USA \\ ${ }^{2}$ Lamar University, Beaumont, TX, USA \\ Correspondence: J. P. Nelson, Department of Political Science, Lamar University, Beaumont, TX 77710, USA.
}

Received: December 14, 2016

Accepted: January 10, $2017 \quad$ Online Published: January 10, 2017

doi:10.11114/smc.v5i1.2075

URL: http://dx.doi.org/10.11114/smc.v5i1.2075

\begin{abstract}
Forced sterilization was an accepted legal practice in the United States during the beginning and middle of the previous century. It was promoted by an international movement to prevent procreation by those deemed unworthy of reproduction (Black, 2003). North Carolina has recently decided to pay reparations to forced sterilization victims (Editorial (Winston-Salem Journal), 2013) and the state of Virginia has more recently emulated this decision (Martz \& Nolan 2015). This analysis will discuss the common eugenic history of many states but will also highlight North Carolina's distinctiveness on this issue. The qualitative portion of the analysis will explain the historical reasons North Carolina would be likely to be the first state to adopt this policy. Our quantitative analysis will examine the role of news coverage of sterilization policy in North Carolina and its relationship to the decision to adopt a policy of reparations.
\end{abstract}

Keywords: reparations, state, sterilization policy, North Carolina, media coverage

\section{Introduction (Note 1)}

Forced sterilization is a policy that was embraced by many American states in the 20th century (Reilly, 1987, p. 155). This policy is deeply inconsistent with the values of present-day American society, but its past use is not as familiar to Americans as other past governmental decisions that violate individual autonomy. These policies intruded deeply into the lives of the individuals affected and are likely not widely discussed due to state variation. US states have diverse histories with regard to sterilization policy (see Reilly, 1987), but North Carolina is unique because of its more recent activity in regard to forced sterilization. It has decided to compensate survivors (Editorial (Winston-Salem Journal), 2013). Virginia has since made the same decision (Martz \& Nolan, 2015), but North Carolina pioneered this policy among US states, so the genesis of the policy in North Carolina will be the focus of this analysis. The central question of this analysis, succinctly stated, is "why North Carolina?". Forced sterilization reparation is an idea that has only recently been enacted by any US state. This is true despite the distinction between forced sterilization and current conceptions of the role of government. This analysis will seek to examine why North Carolina would pioneer reparation for this past policy when it was far from the only state practicing forced sterilization. Exploring what distinguishes North Carolina in this way was the motivation for this study and informs the research questions and related analysis.

Contemporary American political values are very distinct from those that facilitated forced sterilization, and this value distinction has come to the forefront in North Carolina during the 21st century. On this subject, The Winston-Salem Journal has recently claimed (Editorial, 2013):

Back in the day, the Journal supported our state's forced sterilization program, as did some of our city's most prominent families and doctors, along with their counterparts statewide. But for almost 11 years, this newspaper has been on a march toward justice with those victims, fighting for compensation.

Within the same article, the Journal also argued "Since soon after the Journal published the 2002 investigative series Against Their Will, politicians have rendered in vain promises of help for those rendered barren by a state that deemed them mentally or physically unfit to reproduce" (Editorial (Winston-Salem Journal), 2013). (Note 2) These are strong assertions about the role of this media source in shaping the sterilization reparations debate in North Carolina, but the Winston-Salem Journal is not alone in making this connection. In the preface to a compilation of the Winston-Salem Journal's articles on this issue, Lombardo asserted "In late 2002 the Winston-Salem Journal published an extraordinary 
series of articles on eugenics, and North Carolina's governor responded by issuing an apology for the abuses of the sterilization program" (i, in Begos et al., 2012). (Note 3) Schoen (2005, p. 241) has also credited "Against Their Will" with prompting an apology from North Carolina's then-current governor as well as the establishment of a commission for considering restitution. Clearly, the Winston-Salem Journal is not alone in crediting the Winston-Salem Journal with keeping this issue on the agenda in the state of North Carolina.

The Journal, however, has made an additional claim about its role in the state's recent decision on this issue. In "A Landmark Victory, at Last”, they asserted the following (Editorial (Winston-Salem Journal), 2013):

There had been little talk in the legislature about compensation this summer, despite constant prodding in our editorials. We, and the victims, also pushed state House Speaker Thom Tillis to win through budget negotiations with his counterpart in the state Senate, Phil Berger.

In the end, that's how Tillis pulled it off, no doubt buttressed by his knowledge that we'd gotten the governor on record as supporting compensation.

This is a strong assertion from the Journal about their importance in this process. The following analysis will examine whether these assertions are supported by the activities of the Winston-Salem Journal, as well as some additional North Carolina news sources, during the relevant time periods.

This study will contribute to the literature on state policy by exploring why North Carolina would pioneer reparations to forced sterilization survivors. Many states practiced forced sterilization but North Carolina was the first to choose to compensate survivors. This analysis will explain why states initially adopted forced sterilization policies, as well as discuss the unique attributes of North Carolina's program that would make the state likely to be the first to adopt reparations. It will also examine whether the media in present-day North Carolina has prompted the public to pay attention to this issue. This aspect of the analysis will determine if the media, the Winston-Salem Journal more particularly, can be credited with setting the agenda in the reparations debate in North Carolina. Thus, this study will clarify the historical reasons why North Carolina would be likely to adopt reparations and analyze the coverage of the contemporary media as the subject was being debated.

\section{Research Questions}

The general concern of this study and its "why North Carolina?" orientation have been established, but the specific questions the research will address merit some additional conversation. The qualitative/historical section of the study will inquire as to why US states, including North Carolina, adopted forced sterilization policies. This will be done through a discussion of eugenic thought and its influence on policy during the nineteenth and twentieth centuries. Beyond discussing the influences on policymakers of the time and why states would choose to adopt eugenic policies, the historical analysis will also address specific aspects of North Carolina's program that distinguished it from those of other states. This will help explain why North Carolina would likely be the first to approve reparations, which is a question central to this study.

The study will also examine the role of media in the contemporary debate over reparations for sterilization survivors. This discussion will follow the qualitative and historical explanations of why states chose to adopt eugenic policies and the discussion of unique attributes of North Carolina's program. Through an analysis of newspaper coverage, the quantitative discussion will examine whether local media sources kept the reparations debate in the state policy discussion. This examination will be conducted by analyzing the volume of related articles preceding significant achievements by the movement for reparations, culminating in the decision of the state to compensate survivors.

\section{The History of Eugenics in the United States}

The origins of the eugenics movement in the United States are best understood in terms of the confluence of several theories that emerged in the mid and late 19th century. The theories surfaced in a number of fields, and their convergence quickly took hold in a variety of public policy contexts. First, genetic theories in the fields of biology, botany, animal husbandry, and sociology converged in a relatively brief period of time - less than fifty years. Second, some state legislatures and public policy entities quickly accepted the legitimacy of these theories and used them to create laws and policies that were rapidly enacted and enforced. Third, the statutory dimensions of the meaning of genetics and the "symptoms" that made an individual a candidate for sterilization were highly ambiguous and therefore left to the subjective interpretation of state boards and commissions. North Carolina - the only state to give statutory authority to social workers to file petitions for the sterilization of their case "subjects" - provided an additional tier to the diagnoses process and, by empowering social workers to make subjective diagnoses of unacceptable "symptoms," allowed official documentation of the socioeconomic and racial dimensions of both involuntary and voluntary sterilization (see Schoen, 2005; 2011).

The publication of Charles Darwin's Origin of Species in 1859 profoundly affected the paradigms of biological study by 
postulating a theory of evolution based on natural selection and survival of the "fittest." Among Darwin's contemporaries was his cousin Francis Galton, a British scientist. Galton, better known as a statistician and for creating the statistical concepts of chi square, regression, and correlation, became a leader of the eugenics movement in Great Britain. Galton's first study in eugenics, Hereditary Genius: An Inquiry into Its Laws and Consequences (1869), explored the hereditary nature of intellectual ability, and was praised by Darwin (Desmond and Moore 1992 in Galton \& Galton, 1998). Four years earlier (1865), Gregor Mendel, an Austrian monk and botanist, published seminal research on the inheritance patterns in pea plants, and demonstrated dominant and recessive "inheritances" that would allow scientists and farmers to predict phenotype among plant offspring. Significantly, Mendel's study was soon followed by the work of August Weismann, a German biologist, on genetic mutation and germinal continuity. In 1883, Weismann first set forth his theory of a "germ plasm" that carried and contained inherited traits. Weismann's germ plasm theory quickly gained the acceptance of American scientists.

While early eugenicists widely accepted Weismann's theory that a "germ plasm" carried and contained genetic traits, they did not agree on which traits were inheritable (Caron, 2008, p. 49). Generally, Weismann's theory held that infections were caused by germs, and inheritance was governed by germ plasm. But, as Pernick explains, the fusion of infection and inheritance became the governing principle in US public health in the early 20th century. "In both common usage and some scientific literature," Pernick writes, "calling a trait 'hereditary' meant that you 'got it from your parents,' regardless of whether 'it' was transmitted by genes or germs, precepts or probate" (1997, p. 1767).

The definition of inheritable traits that were deemed "acceptable" grounds for eugenic sterilization was initially rooted in the vague and ambiguous term "feeblemindedness." Pro-sterilization articles in medical literature abounded in the early 1900s, peaked in 1910, and almost unanimously favored involuntary sterilization of the "feebleminded" (Reilly, 1987, p. 155). The definition of "feeblemindedness" quickly expanded to include a wide range of unacceptable "inherited" traits including alcoholism, epilepsy, retardation, and sexual promiscuity. Three significant developments, in addition to genetic research, greatly influenced public opinion about what constituted acceptable grounds for eugenic sterilization, and were significantly reflected in the growing number of state statutes that authorized eugenic sterilization.

The first development was renewed interest in Richard Dugdale's 1875 publication of the "Jukes," which contained a detailed account of a New York family with a propensity for taverns, brothels, jails, and almshouses. Publication of the "Jukes" had created a new field in sociology that concentrated on field studies of "degenerate families" (Reilly, 1987) and served to lend credence to the idea that certain unacceptable behaviors such as prostitution, pauperism, and crime were inherited. The second development was the publication of Henry Herbert Goddard's study of students in the New Jersey Training School for Feeble-Minded Girls and Boys, which had an immediate impact on the study of eugenics. Using an intelligence test developed by Alfred Binet, a French psychologist, Goddard tested the intellectual capacity of children in the school, and in 1908 published his findings in "The Binet and Simon Tests of Intellectual Capacity." Use of the Binet Intelligence Quotient (IQ) test spread rapidly and gained overwhelming approval of American psychologists. By 1914, Goddard had introduced the test to public schools, tested immigrants at Ellis Island, and became the first psychologist to introduce evidence from Binet tests in a court of law (Benjamin, 2009, p. 20). IQ testing allowed authorities the ability to verify the diagnosis of "feeblemindedness" in order to implement and carry out state eugenic programs, and assured scientists that mental capacity could be measured in order to confirm diagnoses of feeblemindedness (Reilly, 1987).

A third development was the founding of the Eugenics Record Office (ERO) in 1910. Charles Davenport, founder of the ERO, was a chicken breeder and agriculturalist as well as a Harvard-trained zoologist, and sought to extend Mendel's work on trait inheritance in plants to the study of the human "germ plasm." In 1907, Davenport produced a seminal study of the inheritance of eye color, and later published studies on the genetics of albinism and neurofibromatosis. Deeply concerned about the relationship between feeblemindedness, sexuality, and deviant behavior, Davenport, with help by the Carnegie Institution, established the Station of Experimental Evolution at Cold Spring Harbor, Long Island, which housed the ERO. At Cold Spring Harbor, Davenport undertook extensive study of human genetics, and produced studies demonstrating that sexually immoral people were also afflicted with criminality and feeblemindedness (Schoen, 2005, p. 93).

\section{The History of State Policy and Eugenics}

It is within the context of these early studies in genetics, biology, botany, sociology, and psychology that states began passing sterilization laws. The nation's first sterilization law, passed by the Indiana legislature in 1907, permitted involuntary sterilization of any habitual criminal diagnosed by physicians as "unimprovable" (Reilly, 1987, p. 154), and served as a model for subsequent state sterilization laws. Significantly, the same year Indiana passed the nation's first sterilization law Galton "invented and defined the term eugenics as "the science of improving inherited stock, not only 
by judicious matings, but by all the influences which give more suitable strains a better chance"'(Galton, 1907 in Galton \& Galton, 1998, p. 99). Thus, the term "inheritable feeblemindedness" came to be understood not only in terms of intellectual capability but also in terms of the social symptoms it produced such as criminality, poverty, promiscuity, illegitimacy, and alcoholism. As Schoen elaborates, eugenic scientists considered feeblemindedness and the undesirable social behaviors it produced to be hereditary, and "sterilization seemed to offer an easy medical solution to complex social problems" (Schoen, 2011, p. 142). Soon after the Indiana sterilization statute was passed, Connecticut, California and Washington followed suit (1909), and by 1917 the legislatures of 17 states had passed sterilization laws, usually by a large majority (Reilly, 1987, p. 158).

Compared to the number of state-mandated sterilizations performed in the United States between 1907 and 1921 approximately 3233 (Laughlin, 1922) - there were a relatively small number of lawsuits challenging the constitutionality of sterilization laws. Twelve state sterilization statutes were challenged in state courts between 1913 and 1918; however, it is notable that seven of the challenged statutes were found to be unconstitutional on grounds of the Eighth Amendment's ban against cruel and unusual punishment, the Sixth Amendment's right to fair trial, or the Due Process Clause (Caron, 2008, p. 55). (Note 4) Rather than deterring state legislatures from passing additional sterilization laws, judicial decisions striking down sterilization statutes merely urged state legislators to use greater caution in crafting their state sterilization laws. Twelve states enacted sterilization statutes between 1923 and 1925, and each contained additional constitutional "precautions" such as parental consent for the sterilization of their minor children and the patient's right to a jury trial on the question of whether he or she was "the potential parent of socially inadequate offspring" (Laughlin, 1926, p. 65).

The constitutionality of state-mandated sterilization came before the US Supreme Court in 1927 in the famous case of Buck v. Bell. Whereas some state judges had been quick to point out the constitutional inadequacies of state sterilization statutes, the Supreme Court clearly embraced the tenets of eugenics. The question of law in the case was whether the Virginia sterilization statute, under which the superintendent of the State Colony for Epileptics and Feeble Minded performed a salpingectomy upon Carrie Buck, violated the Due Process Clause and the Equal Protection Clause of the Fourteenth Amendment. Justice Oliver Wendell Holmes, writing for the majority, held that both Carrie Buck and her mother were "feebleminded" and that Carrie Buck's seven-month-old daughter had inherited the family's feeblemindedness. The Court's endorsement of eugenic theory is evident in the following passage from the opinion:

We have seen more than once that the public welfare may call upon the best citizens for their lives. It would be strange if it could not call upon those who already sap the strength of the State for these lesser sacrifices, often not felt to be such by those concerned, in order to prevent our being swamped with incompetence. It is better for all the world if, instead of waiting to execute degenerate offspring for crime or to let them starve for their imbecility, society can prevent those who are manifestly unfit from continuing their kind. The principle that sustains compulsory vaccination is broad enough to cover cutting the Fallopian tubes. (Note 5)

In a footnote to the opinion, Justice Holmes added: "Three generations of imbeciles are enough". (Note 6)

The Carrie Buck decision firmly established the constitutionality of state eugenics statutes and codified the understanding that states were free to enact such statutes, and that the Supreme Court would endorse eugenical sterilization as a benefit to society. New state sterilization laws proliferated in the wake of the decision, and by 1929, 30 states - including North Carolina - had passed sterilization laws inspired by eugenic science (Schoen, 2011, p. 142). The number of eugenical sterilizations continued to rise exponentially after the Buck decision. From the passage of the first sterilization law in 1907 until the mid-1970s when sterilization programs in the US finally ceased, over 63000 people nationwide received eugenic sterilizations (Schoen, 2011, p. 142). California led the way with almost 20000 sterilizations, followed by North Carolina with over 7600 sterilizations and Virginia with over 7000 sterilizations (Schoen, 2005, p. 82).

The eugenic sterilization movement in the US had its share of scientific critics since its inception; however, scientific critique had little effect on public attitudes (Schoen, 2005, p. 104). And, while one might be logically inclined to assume the Great Depression had a deterrent effect on eugenic theory and practice (since the theory advanced the idea that two of the social behaviors exhibited by "feeblemindedness" - unemployment and poverty - were widespread), both "scientists and the general public were unwilling to dismantle programs that seemed to promise a solution to poverty and poor health" (Schoen, 2005, p. 104). In fact, in 1929 there was a large increase in sterilizations and through the 1930s more than 2000 institutionalized persons were sterilized each year - a rate triple that of the early 1920s (Reilly, 1987, p. 162). It was not until the onset of World War II that interest in eugenic sterilization and the practice of state-mandated sterilization began to decline. The decline is most likely attributed to a number of factors including the revelation of genetic atrocities by the Nazis; the rise in the number and quality of scientific challenges to the methodology and assumptions employed in eugenic studies; and the shift in public understandings about the proper 
balance between individual human rights and the promotion of societal interests, as highlighted by the civil rights movement.

The Supreme Court clearly demonstrated its transformed perception of eugenics and the proper balance between individual rights and societal interest when, in 1942, it struck down an Oklahoma law that authorized the involuntary sterilization of thrice-convicted felons. Skinner v. Oklahoma was a landmark case not only because the Supreme Court struck down a state eugenics law, but also because it established that state laws that restricted basic human and constitutional rights would be held to a high legal standard of "strict scrutiny," meaning the state - not the individual had the burden of proof to show a compelling state interest in retaining laws that restricted individual rights. (Note 7) While the Skinner case did not reverse the Court's decision in Buck v. Bell, it did send a clear signal to the states that eugenic sterilization laws would be held under a judicial microscope, and that the Court no longer embraced the tenets of eugenic theory.

Only half as many eugenic sterilizations were performed annually between 1942 (the year of the Skinner decision) and 1946 than had been performed annually during the 1930s (Reilly, 1987, p. 165). The number of eugenic sterilizations consistently fell throughout the 1950s, and in 1962 President John Kennedy established the President's Commission on Mental Retardation which firmly rejected eugenic sterilization. By the early 1960s, most state sterilization programs had ceased (Reilly, 1987, p. 165); however, as state sterilization declined in most states, there was an increase in involuntary sterilizations performed in the states of North Carolina, Georgia, and Virginia (Reilly, 1987, p. 166). In 1944, these three states were responsible for sterilizing $24 \%$ of the nation's total; in 1958 they sterilized $76 \%$ of the nation's total (Schoen, 2011, p. 148).

\section{Unique Attributes of North Carolina Eugenics}

While North Carolina was not the only state to extend its eugenics program after almost all other states had discontinued their programs, it is the first state to have adopted a policy to pay reparations to the surviving victims of the state's involuntary sterilization program. In order to understand why North Carolina news sources would draw attention to the state's eugenic history and expect residents to be supportive of reparations as a result it is important to highlight three unique features of the state's sterilization program while the program was in place. North Carolina was the only state to:

(a) directly and expansively target non-institutionalized, rural young women (Woodside, 1950);

(b) give statutory authority to the Department of Public Welfare and social workers to file petitions for the sterilization of their case "subjects" (Schoen, 2005, p. 106-7) and;

(c) have exceptionally strong support by state media in the volume and content of articles promoting the benefits of eugenics and involuntary sterilization (see Begos, 2002).

Schoen points out that the rising cost of welfare to offset poverty in North Carolina played a leading role in the state's continued use of eugenic sterilization (2011, p. 149). As the welfare rolls grew in the 1950s and 1960s, eugenic sterilization programs in North Carolina expanded (Schoen, 2011, p. 149). Budgetary concerns were not lost on the state's commissioner of public welfare, Ellen Winston, who held the post from 1944 until 1963. During the 1950s, Winston steadfastly defended the importance of and need for the Aid for Dependent Children (ADC) program while simultaneously promoting an aggressive agenda for the state's eugenic sterilization program (Schoen, 2005, p. 105). In 1951, Winston recommended that the state expand its use of eugenic sterilization by following up on ADC recipient families in which one family member had been sterilized to determine if other members might benefit from the surgery (Schoen, 2005, p. 109). The recommendation was adopted, and due to the welfare recipient dimension of the state eugenic sterilization program, the North Carolina Department of Public Welfare came to play the significant and unusual role of executing the state's eugenic sterilization program. Under Winston's plan, execution of the state's eugenic sterilization program expanded in the 1950s and 1960s (Schoen, 2005, p. 106-7).

As the "ADC recipient" category entered into the diagnostic language of the North Carolina eugenics program, a significant shift occurred in the racial composition of those targeted for eugenic sterilization (Schoen, 2011, p. 149). Nationwide, the percentage of welfare recipients who were African American rose from 31\% in 1950 to $48 \%$ in 1961. Significantly, in North Carolina, the proportion of African Americans who underwent eugenic sterilization rose from 23\% of total sterilization cases in the state in the 1930s, to 64\% between 1964 and 1966 (Schoen, 2011, p. 149-50).

The North Carolina news media continued its long established support for the state's eugenic sterilization program. Gordon Gray, former owner of the Winston-Salem Journal and Sentinel, was cousins with Alice Shelton Gray, a founding member of Winston-Salem based Human Betterment League (HBL) (Begos, 2002). The HBL was incorporated 22 March 1947, "and the very next day, there was a favorable mention about sterilization on the editorial page of the Sunday Journal and Sentinel"'(Begos, 2002). Papers throughout the state began running articles praising the 
sterilization program, and minutes from a 1948 HBL meeting contained a suggestion to send letters extolling sterilization to every newspaper published in the state (Begos, 2002). The editorial page editor of the Durham Morning Herald joined the HBL in the 1960s, and even into the 1970s the Winston-Salem Journal continued to promote the state's involuntary sterilization program (Begos, 2002). "Certainly, any role that the Journal played in advocating forced sterilization is reprehensible," stated the 2002 publisher of the Journal. "On behalf of the Journal I apologize for the paper's part in depriving these individuals of their basic human rights" (Jon Witherspoon quoted in Begos, 2002).

North Carolina finally dismantled its involuntary sterilization program in 1975. Almost thirty years later, the Winston-Salem Journal published "Against Their Will," a series of articles that drew attention to the state's 20th century forced sterilization program. The series ran for a period of five days beginning on 8 December 2002, and culminated in a public apology by Governor Mike Easley (Schoen, 2006, p. 8) on 16 December 2002. In February 2003, Governor Easley appointed a special commission to consider restitution to the victims of North Carolina's involuntary sterilization program (Schoen, 2006, p. 8) as well as an exhibit to remember the state's history of eugenic sterilization (Schoen, 2011, p. 155). Although restitution of victims was first presented in 2003, the state legislature did not formally approve and budget the payment of reparations to the surviving victims of North Carolina's eugenic sterilization program until 25 July 2013 (Cohen, 2013). Governor Pat McCrory signed the bill into law, and reparations were scheduled to be disbursed to the victims in 2015 (Neuman, 2013).

\section{Data}

The relationship between the state news media coverage and North Carolina's formal apology for its past of eugenic sterilization appears strong; however, no quantitative studies have been conducted to verify the relationship. Furthermore, no studies have explored the relationship between state media coverage and the passage of the state's $\$ 10$ million appropriations bill to provide reparations to the surviving victims of the state's sterilization program (see Editorial (Winston-Salem Journal), 2013). Our analysis concentrates on state media coverage of the issue and its germaneness to North Carolina's recent decision to pay reparations. Media coverage can frame how voters perceive issues (Zaller, 1992) and different media sources frame the same issue in varied ways (Page, 1996). At the national level, media were not found to strongly influence the governmental agenda (Kingdon, 1995, p. 58); however, we expect different results when examining local media coverage of a state-specific issue. We expect the volume and timing of the coverage to be consistent with the Winston-Salem Journal setting the agenda on this issue.

The focus of our analysis is on the volume of coverage of sterilization policy in three major newspapers in North Carolina: the Winston-Salem Journal, The Charlotte Observer, and The News and Observer. The "Against Their Will" series published by the Winston-Salem Journal is expected to shape a great deal of the pattern in the coverage. Our analysis begins in 2000 and examines news coverage of the involuntary sterilization issue in North Carolina at the beginning of the 21st century through December 2013.

Some additional background on how this issue came to light in North Carolina is necessary to understand our selection of sources and the time period analyzed. In 1996 Schoen conducted research in North Carolina's State Archives and was given access to minutes from Eugenics Board meetings spanning over thirty years. Schoen was allowed to retain copies of the minutes, though the names of individuals whose possible sterilization was being discussed were redacted from the copies (Schoen, 2005, p. 242-3). The North Carolina State Archives later closed these same records and researchers were not allowed access to them (Schoen, 2005, p. 243). In the aftermath of Virginia's gubernatorial apology for their state's history of sterilization, Schoen contacted The News \& Observer about this story in 2001, but characterized their response as very limited (2005, p. 243). Schoen (2005, p. 243-4) explained the rest of this process as follows:

In June 2002, however, Kevin Begos from the Winston-Salem Journal called. After talking to him over the course of several weeks, I decided to offer him full access to my yet unpublished research findings and all of the sources I had collected in years of research, including the summaries of the eight thousand sterilization petitions. I felt I had an ethical responsibility toward those who had been sterilized under the program, that I owed them a form of public recognition. A newspaper series would bring the story to the attention of the larger public, and Kevin was the right person to write it...

Given the discussion of how this information became part of public debate in North Carolina, it is clear why the analysis begins in the year 2000. It leaves at least one year prior to these events to assess whether coverage has changed. Also, the Winston-Salem Journal and The News \& Observer are obvious candidates for analysis because of their role in the exposure of this information to the public. The Charlotte Observer will be analyzed in the same time period to assess the coverage of the issue in another large city in North Carolina. The last year included in the analysis is 2013 because that is the year of the reparation decision and the analysis is concerned with the role of the media in how North Carolina came to that decision.

Our data was gathered by compiling from NewsBank (Note 8) all available articles in the Winston-Salem Journal, The 
Charlotte Observer and The News \& Observer that contained the word "sterilization." Attempts to gather data using more specific phrases (i.e. "eugenic sterilization," "forced sterilization," and "involuntary sterilization") resulted in few articles and omissions of potentially important data. Once we compiled the articles, we examined each to determine if American sterilization policy was discussed in the article. If sterilization was discussed in another context, the article was omitted from our analysis. Letters to the editor and other commentaries and feedback from readers were also dropped because we sought to examine only articles written by reporters and other agents of the respective news outlets. Even omitting letters to editor, a great deal of information was gathered by examining the remaining 448 articles gathered across the fourteen years included in our analysis. (Note 9) Each article represents a decision by one of the three newspapers to cover sterilization policy, and they are not evenly spread across the papers or the years included. As Table 1 illustrates, there is a definite temporal trend in the coverage.

Table 1. Total Articles by Year and Newspaper.

\begin{tabular}{llllll}
\hline Year & $\begin{array}{l}\text { The Charlotte } \\
\text { Observer }\end{array}$ & The News \& Observer & Winston-Salem Journal & \%Winston-Salem Journal & Total Articles \\
\hline 2000 & 0 & 0 & 1 & $100 \%$ & 1 \\
2001 & 1 & 1 & 0 & 0 & 2 \\
2002 & 4 & 0 & 33 & 89 & 37 \\
2003 & 17 & 12 & 43 & 60 & 72 \\
2004 & 4 & 0 & 4 & 50 & 8 \\
2005 & 4 & 2 & 9 & 60 & 15 \\
2006 & 0 & 7 & 3 & 30 & 10 \\
2007 & 1 & 4 & 11 & 69 & 20 \\
2008 & 1 & 4 & 15 & 75 & 19 \\
2009 & 1 & 7 & 11 & 58 & 12 \\
2010 & 0 & 0 & 12 & 100 & 81 \\
2011 & 16 & 15 & 50 & 52 & 101 \\
2012 & 23 & 22 & 56 & 55 & 55 \\
2013 & 12 & 7 & 35 & 63 & 448 \\
Total Articles & 84 & 81 & 283 & & \\
\hline
\end{tabular}

\section{Findings}

Coverage of the issue of sterilization in the years 2000 and 2001 is virtually nonexistent, as Tables 1 demonstrates. A total of only three articles were found across the first two years of our study. Conversely, there was an extremely high volume of coverage devoted to sterilization policy in the years 2002 and 2003 especially in comparison to the years 2000 and 2001. In 2002 and 2003, a combined total of 109 articles were published on the issue across the three newspapers, and the Winston-Salem Journal published the "Against Their Will" series near the end of 2002. Whether the official apology discussed above caused the volume of coverage at the end of 2002, or whether the media coverage of 2002 triggered the apology, is an obvious question that necessitates attention here. As Table 2 demonstrates, all of the news coverage of the sterilization issue during December 2002 occurred prior to Governor Easley's apology on December 16, and over $90 \%$ of the coverage came from the Winston-Salem Journal. Our finding demonstrates that media attention to the sterilization issue was prior to the state's formal apology, not vice versa. The Winston-Salem Journal did not merely report on recent developments in state policy; rather, its coverage of the sterilization issue is consistent with the newspaper prompting action from the state. The uniqueness of the "Against Their Will" series' content and timing bolsters this causal claim. There was very little coverage of the issue prior to the Winston-Salem Journal's extremely focused attempt to inform the public about forced sterilization.

Table 2. Total Articles by Day and Newspaper. All Newspapers: December 2002.

\begin{tabular}{lllll}
\hline Day & The Charlotte Observer & The News \& Observer & Winston-Salem Journal & Total Articles \\
\hline 8 December 2002 & 0 & 0 & 5 & 5 \\
9 December 2002 & 0 & 0 & 5 & 5 \\
10 December 2002 & 1 & 0 & 5 & 6 \\
11 December 2002 & 0 & 0 & 7 & 7 \\
12 December 2002 & 0 & 0 & 7 & 7 \\
13 December 2002 & 0 & 0 & 1 & 1 \\
14 December 2002 & 2 & 0 & 1 & 3 \\
15 December 2002 & 0 & 0 & 2 & 2 \\
Total Articles & 3 & 0 & 33 & 36 \\
\hline
\end{tabular}

Note: Omitted days did not contain any of our data. The days listed are the only ones relevant to the analysis.

Table 1 demonstrates the emergence of a pattern of media coverage of the sterilization issue after 2003. From $2003-$ 2010, media coverage of sterilization is more sparse. In the years 2004-2010, the three newspapers combined published only 100 articles on the subject, averaging, 14.29 per year, or slightly more than one per month. This is more coverage 
than in 2000 and 2001; but the newspapers clearly assigned less priority to the sterilization issue from $2004-2010$ than they did in 2002 - 2003. During the years 2004 - 2010, the three North Carolina newspapers we analyzed clearly focused on other issues or saw less value in covering sterilization policy than they did in 2002 and 2003.

Another pattern is clearly visible in the 2011-2013 timeframe. In this period, the newspapers published 236 articles on the subject of sterilization, including 81 in 2011 and 101 in 2012. All of the articles in the data between August 5, 2009 and May 15, 2011 were published in the Winston-Salem Journal. As evidenced by Table 1 the other sources clearly emphasized this debate later in 2011. Later in the year there were more developments to discuss and other sources were reporting on the issue. On 26 June 2011 The News \& Observer laid out their editorial position in an article title "Compensation - There's no way to make up for what state-sponsored sterilizations did, but money is something" (pp. 16A). In this article The News \& Observer explained that Governor Perdue had established a Eugenics Task Force which heard the testimony of forced sterilization survivors during the previous week. Later in the year, another development prompted coverage of the issue when Thom Tillis, the Speaker of the North Carolina House, expressed his support for forced sterilization compensation (Helms \& Tomlinson, The Charlotte Observer, 25 August 2011). Helms and Tomlinson also credited state representative Larry Womble, who had submitted many forced sterilization compensation bills, with asserting that his bills on this issue never made it to the floor under the two speakers that preceded Tillis.

Thus, in addition to the Winston-Salem Journal's consistent attention to forced sterilization, other developments in the executive and legislative branches of state government prompted coverage of the issue. These both likely contributed to the increase in coverage in 2011. Exactly how much each newspaper is responsible for the high volume of coverage from 2011 to 2013 will be examined in greater detail below in our discussion of coverage by each newspaper during those years.

There was wide variation in coverage of the sterilization issue by each respective newspaper across the years included in our analysis (see Table 1). As expected, the Winston-Salem Journal devoted more attention to the issue than The News \& Observer and The Charlotte Observer. In every year other than 2001 and 2006 at least half of the total coverage was from the Winston-Salem Journal. Notably, 89\% of the coverage in 2002 and 60\% of the coverage in 2003 was from the Winston-Salem Journal. The Winston-Salem Journal also sustained media attention to this issue in years with little coverage of the issue overall from 2004-2010. Whenever coverage trended upward again after 2010, the Journal provided most of the coverage of the issue among the three papers, and also provided most of the coverage overall $(63 \%)$ during the time period analyzed. The "Against Their Will" series clearly is not the entire story of how attention has been brought to the sterilization program in North Carolina; however, the newspaper that published the series has been consistent in its coverage of the issue since the series was published in 2002. Significantly, The News \& Observer and The Charlotte Observer dramatically increased their coverage of the sterilization issue the year after the Winston-Salem Journal ran the "Against Their Will" series. The News \& Observer did not publish any articles on the subject in 2002 and published 12 in 2003; The Charlotte Observer published only four sterilization articles in 2002 and published 17 in 2003. The Winston-Salem Journal had the most articles on the sterilization issue during the $2002-2003$ time period with 33 in 2002 and 43 in 2003, and their coverage seems to have influenced the other papers with respect to their attention to the subject. The Journal also seems to have brought attention back to the issue in 2011 when it published 50 articles on the subject, beating its own previous record of 43 articles on the subject of sterilization in 2003. In 2012, the other two newspapers increased their coverage of the issue as well.

Table 3 below set forth the total coverage of articles on sterilization by the three newspapers as well as a breakdown of coverage by each respective newspaper in the month of July 2013. We focus on July 2013 because it is the month and year in which the North Carolina state legislature formally approved and budgeted the payment of reparations to the surviving victims of the state's eugenic sterilization program (25 July 2013). It is possible that legislative discussion about reparation impacted the amount of newspaper coverage of the sterilization issue in July 2013, but most of the stories on sterilization during the month (10 of 12) were published before the actual state legislative decision. In this context, the Journal and the other two newspapers were reporting not only on the political dynamics of reparation but also on the issue of sterilization itself. It is significant to note that all of the Journal's news stories on sterilization in July 2013 were published before the legislature's reparation decision. 
Table 3. Total Articles by Day and Newspaper. All Newspapers: July 2013.

\begin{tabular}{lllll}
\hline Day & The Charlotte Observer & The News \& Observer & Winston-Salem Journal & Total Articles \\
8 July 2013 & 1 & 0 & 0 & 1 \\
17 July 2013 & 0 & 0 & 1 & 1 \\
22 July 2013 & 1 & 2 & 0 & 3 \\
23 July 2013 & 0 & 0 & 3 & 3 \\
24 July 2013 & 2 & 0 & 0 & 2 \\
28 July 2013 & 1 & 1 & 0 & 2 \\
Total Articles & 5 & 3 & 4 & 12 \\
\hline
\end{tabular}

Note: Omitted days did not contain any of our data. The days listed are the only ones relevant to the analysis.

\section{Conclusion}

There are many unique features about North Carolina's history of involuntary sterilization and it was the first state to approve and budget reparations to surviving persons who were subjected to involuntary sterilization by the state's eugenics laws. North Carolina is one of only two states to make that decision and pioneered this approach to the eugenic history of American state policy. In this paper, we have outlined the history of the eugenics movement in the US, and highlighted some of the important features of the North Carolina state sterilization program. While discussing these features we showed why journalists would assume they could generate support for reparations by covering the program. We then tested whether the volume and timing of the coverage was consistent with the newspapers shaping the debate. Our data focused on temporal trends in newspaper coverage of the sterilization issue by three of the state's newspapers the Winston-Salem Journal, The Charlotte Observer, and The News \& Observer. We hypothesized that the volume and timing of local newspaper coverage of the issue would be consistent with the newspapers, particularly the Journal, having an impact on the behavior of state officials as they debated how to address the old program.

The role newspaper coverage played in perpetuating North Carolina's involuntary sterilization program after almost all other states had discontinued their sterilization programs was not the immediate focus of our study; however, secondary research and admission by the Winston-Salem Journal itself demonstrates that newspaper coverage of eugenics did play a role in promoting the state's sterilization program until the state's cessation of the program in 1975 . Our primary research demonstrates that newspaper coverage continued to have an impact on the state's sterilization policies. First, state newspapers resurrected the sterilization issue close to thirty years after the program ended. Renewed attention to the state's history of sterilization began with the Journal's publication of the "Against Their Will" series in December 2002. While there were only three total articles published on sterilization in 2000 and 2001, our data demonstrates that 109 articles were published on the subject in the next two years, and that all of the coverage in 2002 occurred prior to Governor Easley's formal apology for the state's history of involuntary sterilization (December 2002). Over 90\% of the coverage in December 2002 came from the Journal.

Second, state newspapers increased their coverage of the state's former sterilization program in 2011-2012. Our study shows that newspaper coverage of the state's sterilization program declined significantly from 2004-2010; but, the Journal once again brought the issue to the forefront in 2011, publishing 50 articles on the subject and spurring on the publication of a combined total of 236 articles by the three newspapers studied in the two-year 2011 and 2012 period alone. The large number of articles published on sterilization in 2011 and 2012 appear to have culminated in the North Carolina legislature's decision to pay reparations to the surviving victims of the state's eugenic sterilization program. It is worth noting that the state formally apologized for the program in 2002 after significant newspaper coverage of the issue, and that the governor appointed a special commission to consider restitution to the victims in early 2003. Our data indicates that after the commission was appointed, newspaper coverage of the sterilization program plummeted. Significantly, the 2004-2010 decrease in newspaper coverage of the program coincides with a ten-year hiatus in legislative decision making on the reparations issue (from the establishment of the restitution commission in 2003 until the state legislature approved reparations in 2013). The legislature's return to the issue of reparations occurred after the three newspapers - and particularly the Journal - substantially increased their coverage of the issue in 2011-2012. Our data also demonstrates that 10 of the 12 newspaper articles published on sterilization in July 2013 - the month the reparations bill passed the North Carolina legislature - were published before the legislature passed the reparations bill. We conclude from our findings that state newspapers and the Journal in particular devoted a great deal of coverage to this issue prior to the gubernatorial apology in 2002 and the reparation decision in 2013. These findings are consistent with causal arguments about the newspapers helping sterilization victims receive reparations.

In 2013 the Winston-Salem Journal claimed that "for almost 11 years, this newspaper has been on a march toward justice with those victims, fighting for compensation" (Editorial, 1 August 2013). As our analysis of the coverage has shown, this is a credible claim for the Winston-Salem Journal to make, particularly in the early 2000s and in 2011 and 2012. From the "Against Their Will" series to the passage of reparations for sterilization survivors, the Winston-Salem 
Journal devoted its resources to keeping the sterilization program on the agenda in the state of North Carolina. The Charlotte Observer and The News \& Observer both contributed substantial coverage of this issue to the public debate in North Carolina, but the Winston-Salem Journal devoted more to this cause. Paying reparations to sterilization survivors is a policy that North Carolina adopted before any other US state and supporters of this policy have reason to commend the Winston-Salem Journal for its attention to the issue over the course of the present century.

\section{References}

Begos, K. (2002, December 9). ALL ABOARD: Newspapers jumped on sterilization bandwagon. Winston-Salem Journal, A13.

Benjamin, L. T. Jr. (2009). The Birth of American Intelligence Testing. Monitor on Psychology, 40(1), 20.

Black, E. (2003). War against the weak: Eugenics and America's campaign to create a master race. New York: Four Walls Eight Windows.

Buck, \& Bell (1927). 274 US 200

Caron, S. (2008). Who chooses? American reproductive history since 1830. Gainesville, FL: University Press of Florida. https://doi.org/10.5744/florida/9780813031996.001.0001

Cohen, E. (2013, July 28). North Carolina lawmakers OK payments for victims of forced sterilization. CNN. Retrieved from http:// www.cnn.com/2013/07/26/us/north-carolina-sterilization-payments/ (accessed 21 September 2015)

Darwin, C. (1859). On the origin of species by means of natural selection, or the preservation of favoured races in the struggle for life. London: Murray.

Davis, \& Berry (1914). 216 Fed. 413.

Desmond, A. J., \& Moore, J. R. (1992). Darwin. London: Penguin.

Dugdale, R. 1877. The Jukes: a study in crime, pauperism, disease, and heredity. New York: G.P. Putnam's Sons. Editorial (Winston-Salem Journal). (2013, August 1). A landmark victory, at last. Winston-Salem Journal, pp. A18.

Galton, D. J., \& Galton, C. J. (1998). Francis Galton: And eugenics today. Journal of Medical Ethics, 24, 99-105. https://doi.org/10.1136/jme.24.2.99

Galton, F. (1869). Hereditary genius: an inquiry into its laws and consequences. London: Macmillan and Co. https://doi.org/10.1037/13474-000

Galton, F. (1907). Inquiries into human faculty and its development. London: Dent and Sons. https://doi.org/10.1037/10913-000

Goddard, H. (1908). The Binet and Simon tests of intellectual capacity. Training School, 5, 3-9.

Helms, A., \& Tomlinson, T. (2011, August 25). Sterilized victims get Tillis's support - Survivors of statewide eugenics program 'need to have it made right,' says House speaker, who wants lawmakers to vote next year on a plan to compensate them. The Charlotte Observer, pp. 1A. In re Thomson, 169 N.Y.S. 638 (Sup. Ct. 1918).

Kingdon, J. W. (1995). Agendas, alternatives, and public policies $\left(^{\text {nd }}\right.$ edition). New York: HarperCollins College Publishers.

Laughlin, H. (1922). Eugenical sterilization in the United States: A report of the Psychopathic Laboratory of the Municipal Court of Chicago. Chicago: The Psychopathic Laboratory of the Municipal Court of Chicago.

Laughlin, H. H. (1926). Historical, legal, and statistical review of eugenical sterilization in the United States. New Haven, CT: American Eugenics Society.

Lombardo, P. A. (2008). Three generations, no imbeciles: Eugenics, the Supreme Court, and Buck v. Bell. Baltimore: The Johns Hopkins University Press.

Lombardo, P. A. (2012). Preface. In K. Begos, D. Deaver, J. Railey, \& S Sexton, Against their will: North Carolina's sterilization program and the campaign for reparations (pp. i-iii). Apalachicola, FL: Gray Oak Books.

Martz, M., \& Nolan, J. (2015, March 26). McAuliffe signs budget, lauds cooperation with legislature. Richmond Times-Dispatch. Retrieved from http://www.richmond.com/news/virginia/government-politics/general-assembly/article_94fb0fbd-80cf-51cf-8bd2-0 ca8b2942e6e.html

Mickle, \& Henrichs (1918). 262 Fed. 687.

Neuman, S. (2013, July 25). North Carolina set to compensate forced sterilization victims. NPR. Retrieved from www.npr.org/blogs/thetwo-way/2013/07/25/205547272/north-carolina-set-to-compensate-forced-sterilization-victims

NewsBank inc. (n.d.). Retrieved from 
http://infoweb.newsbank.com.libproxy.lamar.edu/iw-search/we/Homepage?p_action=doc\&p_theme=current\&p_nb id=Q65B56LSMTQ1ODMyODI0OC40MzQyMDU6MToxNDoxMzIuMTc0LjI1NC45Nw

Page, B. (1996). Who deliberates? Mass media in modern democracy. Chicago: University of Chicago Press.

Pernick, M. S. (1997). Eugenics and public health in American history. American Journal of Public Health, 87, 1767-1772. https://doi.org/10.2105/AJPH.87.11.1767

Reilly, P. R. (1987). Involuntary sterilization in the United States: A surgical solution. The Quarterly Review of Biology, 62, 153-170. https://doi.org/10.1086/415404

Schoen, J. (2005). Choice and coercion: Birth control, sterilization, and abortion in public health and welfare. Chapel Hill, NC: University of North Carolina Press.

Schoen, J. (2006). From the footnotes to the headlines: Sterilization apologies and their lessons. Sexuality Research and Social Policy, 3(3), 7-22. https://doi.org/10.1525/srsp.2006.3.3.7

Schoen, J. (2011). Reassessing eugenic sterilization: The case of North Carolina. In P. Lombardo (Ed.), A century of eugenics in America: From the Indiana experiment to the human genome era (pp. 141-160). Bloomington, IN: Indiana University Press.

Skinner, \& Oklahoma, E. R. W. (1942). 316 US 535

Stata, C. (2011). Stata Statistical Software: Release 12. College Station, TX: Stata Corp LP.

State, \& Feilen (1912). 70 Wash. 65, 126 Pac. 75

The News \& Observer. (2011, June 26). Compensation-There's no way to make up for what state-sponsored sterilizations did, but money is something. The News \& Observer, 16A.

Winston-Salem Journal. (2002). Against their will. Retrieved from http://www.journalnow.com/specialreports/againsttheirwill/

Woodside, M. (1950). Sterilization in North Carolina: A sociological and psychological study. Chapel Hill, NC: University of North Carolina Press.

Zaller, J. (1992). The nature and origins of mass opinion. New York: Cambridge University Press. https://doi.org/10.1017/CBO9780511818691

\section{Notes}

Note 1. The corresponding author will provide the data analyzed below to those interested in replication.

Note 2. For more information on 'Against Their Will' including the original articles see Winston-Salem Journal, Against their will. Retrieved from http://www.journalnow.com/specialreports/againsttheirwill/

Note 3. As noted in Lombardo in Begos et al. (2012, p. iii) Paul Lombardo also wrote Three Generations No Imbeciles: Eugenics, the Supreme Court \& Buck v. Bell. Lombardo's (2008) Three Generations No Imbeciles is a valuable resource for readers interested in American forced sterilization, but will not be discussed extensively in the following analysis due to its heavy focus on the state of Virginia.

Note 4. See, for example, State v. Feilen, 70 Wash. 65, 126 Pac. 75 (1912), Mickle v. Henrichs (1918) 262 Fed. 687, Davis v. Berry (1914) 216 Fed. 413, and In re Thomson, 169 N.Y.S. 638 (Sup. Ct. 1918).

Note 5. Oliver Wendell Holmes, majority opinion, Buck v. Bell, (274 US 200, 47 S.Ct. 584), $1927,207$.

Note 6. Oliver Wendell Holmes, majority opinion, Buck v. Bell, (274 US 200, 47 S.Ct. 584), 1927, 207.

Note 7. Skinner v. Oklahoma Ex Rel. Williamson, 316 US 535 (1942).

Note 8. NewsBank inc. (n.d.). Retrieved from http://infoweb.newsbank.com.libproxy.lamar.edu/iw-search/we/Homepage?p_action=doc\&p_theme=current\&p_nbid= Q65B56LSMTQ1ODMyODI0OC40MzQyMDU6MToxNDoxMzIuMTc0LjI1NC45Nw

Note 9. We analyzed the data using Stata 12. StataCorp LP, Stata Statistical Software: Release 12 (College Station, TX 2011).

\section{Copyrights}

Copyright for this article is retained by the author(s), with first publication rights granted to the journal.

This is an open-access article distributed under the terms and conditions of the Creative Commons Attribution license which permits unrestricted use, distribution, and reproduction in any medium, provided the original work is properly cited. 